\title{
Household composition and the dynamics of community-based social care in England - CORRIGENDUM
}

José Iparraguirre

(First published online 28 April 2021)

https://doi.org/10.1017/S0144686X19000199, Published online by Cambridge University Press, 19 March 2019

Key words: long-term care; dynamic models; local government; corrigendum

This article was originally published without including José Iparraguire's second affiliation, as a $\mathrm{PhD}$ student at Universidad Nacional de Educación a Distancia (UNED), Madrid, Spain. This has now been updated and this corrigendum published.

\section{Reference}

Iparraguire J (2020). Household composition and the dynamics of community-based social care in England. Ageing \& Society 40, 1631-1646. https://doi.org/10.1017/S0144686X19000199

Cite this article: Iparraguirre J (2022). Household composition and the dynamics of community-based social care in England-CORRIGENDUM. Ageing \& Society 42, 743-743. https://doi.org/10.1017/ S0144686X2100057X

(C) The Author(s), 2021. Published by Cambridge University Press 